Reviews

studies, the volume is a valuable addition to the growing literature on a "new world disorder" that seems to be ever-expanding and intensifying.

\title{
A Claim to Land by the River: A Household in Senegal 1720-1994. By Adrian Adams and Jaabe So, 1996. Oxford: Oxford University Press. 300 pp.
}

\section{Reviewed by Olga F. Linares, Senior Scientist, Smithsonian Tropical Research Institute, Panama.}

A Claim to Land in the River chronicles the experiences of a Soninke family residing in one of many communities located along the Senegal River Valley: how its members attempt to forge a secure livelihood during two hundred years of frequent moves in village residence, shifts in land ownership and family practices, cycles in household composition and individual wage migrations. It is the story of at least eight generations of men and women in constant struggle against every conceivable adversity. These include natural disasters, the incursion of warring neighbors, colonial forms of taxation, and the post-independence policies of an overencompassing Senegalese State.

At stake nowadays is the right of numerous communities along the River to organize in defense of peasant farming. The Federation they have chartered seeks autonomy for its officers, so they can negotiate on behalf of community members for the kinds and amounts of loans and subsidies they need from hegemonic State agencies backed by foreign aid. On this Association lies the hope of many Soninke peasant farmers to master the technique of pump irrigation. Theirs is a complex production system combining flood recession farming with rain-fed cultivation further inland. To succeed in this unpredictable, drought-driven environment, the waters of the River must be harnessed. Their life-giving moisture needs to be managed efficiently, at the grass roots level, by experienced farmers who know the lay of the land and are fully committed to a participatory form of communal development. This, in essence, is the central message of this intriguing book. My purpose in the pages that follow is to provide a synopsis of the main events recounted in the book, and comment upon them. By doing so, I hope to guide the reader through the intricacies of a narration that involves various time-frames, many individual personalities and collectivities, multiple localities, numerous NGO's and State agencies and endless bureaucratic entanglements.

The main text of the story is built upon the narrations of individual Soninke actors. Principal among the speakers is the respected elder Jaabe So, the actual President of the Féderation des Paysans Organisés du Département de Bakel. His ancestors founded the community of Kungani on the left bank of the Senegal River. In the initial chapters, Jaabe So explains how the founders and their descendents brought the land under cultivation despite constant wars by neighboring warring factions, the threats of evil spirits, and the "tubab," with their superior ways. He recounts how founders allotted parcels to later-day arrivals until every section of riverine land was owned. Owners included the households of Muslim clerics, who farmed with help from their disciples, and households belonging to the descendents of village founders, or of their slaves. Jaaba So describes the farming practices of his father, Amma So. A dedicated farmer, Amma would cultivate maize and sorghum on the narrow strip of land along the inner bank of the Great River as the flood waters receded; then he would grow calabash and pumpkins further downslope, and also sweet potatoes and cowpeas, producing more than the family could eat.

Jaabe So's account of events from 1720 to 1938 is complemented by the voices of secondary actors, named individually. They fill in the story with further details concerning new waves of 
Reviews

settlement, fresh grants of land needing clearance, approved or frowned upon marriage unions, and strategic alliances against the Fula, and the treacherous "tubab." All these narratives of initial beginnings are thick with proper names of individuals, the towns they visited and the social groups they encountered.

A second, prominent voice in the narrative, does much to clear the way for the reader. Adrian Adams, the anthropologist who co-authored the book with Jaabe So, is well known for her previous studies of Soninke migrants to France and elsewhere. Adams provides background clarification of who is who, and what role he/she played in Kungani's history. She also supplies useful quantitative data on how much land each household owns, and documents where households farmed - along the riverside, or further inland in the "jeeri" - and with whom - their kin, their former slaves, their Koranic students, or members of neighborhood societies. In subsequent chapters she raises her voice in anger against the duplicity of government officials and the complicity of foreign aid workers.

A third, more passive source of information for these two initial chapters comes from the extracts of praise-songs, from early descriptions by travelers and colonial officers, and from anonymous archival accounts. Together with the contributions of principal speakers and secondary actors, they provide a nuanced picture of how farming took place then, and how it does now. Two kinds of flooded riverine land were and are still farmed up and downstream from Kungani: the floodplain, and the recession line fringing the inner bank. In both, parcels are individually owned and permanently cropped, year after year. But Kungani's main farmlands are located two to ten miles [3.2 to $16 \mathrm{~km}$ ] inland, along the rocky hills. These rain-fed lands belong to the community. They are cleared by groups of households, who plant sorghum, maize and groundnuts for several years, then move on to a different place to cultivate. After a period of fallow, the same parcels are farmed again, by a different group.

The next chapter in the book (Ch. 3) recounts the migratory saga of particular Soninke individuals between 1937 and 1968. Much of the narration is done by Jaabe So himself, with background comments provided by Adrian Adams. Jaabe So recollects the first trip he made in 1936 on foot, from Bakel to Dakar, the months he spent working as a seasonal laborer in Kaolack, the job he afterwards had with the Shell Company filling drums in Dakar. At that time (1936) he was one of 25 or so Kungani men working for wages. (Many years later, in 1977, over 200 men from Kungani were working in France). Anyhow, during the war years, Jaabe So enlisted in the navy, serving on board a submarine supply vessel. After the war ended, he joined the merchant marine in 1946 and began to most instructive years of his early career. He observed oxen ploughing maize fields in Brazil, irrigation canals in Avignon, a complex network of main and secondary canals for multiple waterings of the sorghum crop in India and the building of furrows to grow maize and vegetables under irrigation in Madagascar. Jaabe So was doing what he intended: "I was looking for knowledge of the world" (p. 85). In 1963, after having retired from the merchant marine, Jaabe So went back home to Kungani, resolved to put his experiences to work. These were post-Independence (that is, post-1960) days, marked by efforts at nation building; the Senegalese State expanded its bureaucracy, creating ONCAD, to control groundnut production as an export crop, but with little success. Production fell, while industry also declined; the only increases registered were in urban migration and unemployment.

Meanwhile, Jaabe So, settled once more in Kungani, began again to farm, but this time using a plough and the oxen he trained himself. The idea caught on among other farmers. It was thus that animal traction was first introduced into the area, by a dynamic innovator bringing in the knowledge he had acquired during 20 years of travel. From 1963-1965, years with good precipitation, Jaabe So harvested copious amounts of grain: maize and sorghum filled his granaries until they overflowed. Then the drought hit in 1966, and from then on grain yields declined spectacularly, year after year. Jaabe So decided irrigation was the solution, and he went back to France, resolved to bring back a pump. He was not alone in judging that irrigation was the way to overcome drought conditions. In 1965, the Société d'Aménagement et d'Exploitation des Terres 


\section{Reviews}

du Delta du Fleuve Sénégal (SAED) was created by the State, to develop large-scale, irrigated rice-farming. Six brand new villages were built; 20,000 new settlers were brought in; 30,000 hectares were to be put into rice production in 10 years. By 1968, however, 20,000 acres $[8,1000$ ha] had yielded only 500 tons of rice. These events were to repeat themselves over and over again. Chimeric schemes, brought to complete failure because the peasants involved were not consulted and often misled. At the end, farmers became deeply indebted to SAED for the fertilizer, seed, and machinery they took on credit and were unable to repay with the meager harvests they obtained. Many farmers opted out of agriculture altogether. They left for France in increasing numbers, to search for salaried work in a society where discrimination against foreigners had grown rampant. Even individuals like Jaabe So, who had risked his life to defend the ungrateful nation, were met with hostility. But he persevered. Not only did he purchase the pump he wanted, but he also extracted a promise from one of the organizers of GRDR (Groupe de Recherches et de Réalisations pour le Développement Rural dans le Tiers Monde) to provide a technician that would reside in Kungani and teach the farmers to irrigate their fields, using pumps.

The years that followed Jaabe So's return to Kungani in 1973, bringing with him a pump, were marked by successful efforts to organize a farming group that would labor on a collective field, and to convince neighboring communities to do the same. They were bitter times also. The government extended SAED's mandate to develop agriculture from Saint-Louis in Senegal, to the Malian border. Robert, the technician sent by GRDR, had joined SAED and left Kungani for Bakel. Confrontation grew between SAED, with its over-reaching plans to re-organize the land into individual family plots, where rice would be grown exclusively, over the entire region, and the Kungani farmers, intent on keeping their independence, to grow the crops they wanted, to continue farming part of the land collectively, and to avoid indebtedness. Faced with this situation, and aware that strength lies in numbers, Jaabe So had the bright idea in 1975 to organize a Federation made up of farmers' groups from several neighboring communities. He had first encountered this form of organization in his travels to Madagascar. The goal of the Federation, in their own terms, was to implement development, gradually, in ways they considered appropriate. And to resist the mandate to grow only irrigated rice on sandy soils that would not retain water. More promising was to diversify.

Members of the Federation elected a board of officers, with Jaabe So as President, and wrote out the statutes. Then followed then trying years of Kafkaesque efforts to get the Federation officially recognized by the Ministry of the Interior. Each of five successive applications, consisting of a hefty dossier, was either rejected outright, pretended to be lost, or forced to be rewritten and/or resubmitted. Finally, in 1985, after numerous appointments with government officials, countless letters, endless trips to Dakar, the Federation was [begrudgingly] signed into agreement. But not without the Federation's directors having to apply further pressure so that SAED would stop sabotaging their activities (by withholding fuel and fertilizer, for example), and openly consult with them. This was never achieved. The Federation had to pursue the path to future development alone, eventually buying its own fuel directly from the B.P., obtaining its own tractors, training its own mechanics, and negotiating directly with independent NGO's (Oxfam, ENDA, GDR, OFADEC, ICCO, etc.) for technical, monetary, and educational assistance.

Meanwhile, in the years following 1975, much had been going on. The Kungani farming group tried growing irrigated rice, and rain-fed sorghum, on individual parcels, as well as on a collective field. For example, in 1977, 120 men, belonging to 85 households, farmed 375 acres [152 ha] of rain-fed and flood-recession land, for a yield of 150 tons of grain, about half the amount they needed. In that same year, over three hundred Kungani married women grew maize near home, and groundnuts, swamp rice, and indigo further away, in inland fields. But the rains were insufficient, and their harvests, like those of their husbands, were meager. In the ensuing years, one household after another also tried to cultivate their flood-recession fields, and/or their rain-fed fields inland, with little success. They harvested nothing, or only a few kilograms of grain. The rains refused to come; all the 1970's were years of drought. Kungani households increasingly depended on purchases of sorghum, rice, oil, fish and meat; they survived thanks to 
Reviews

remittances from kin working abroad.

What grew unhampered in those and latter years were grand development plans, expensive schemes, and tricky adjustment programs, all devised by the Senegalese State, largely financed by foreign grants and loans. US AID set the conditions that SAED was to follow if it wanted to receive their grants (US\$6 million plus in 1975, for example. Again, the stipulation was for farmers to divide the collective field into family plots and grow rice exclusively.

Time and time again SAED tried to have Federation members sign contracts that were detrimental to their interests. The Organisation pour le Mise en Valeur du Fleuve Sénégal (OMVS), created in 1972, began building a dam at Diama, on the mouth of the Senegal River in 1981, and Manantali, in Mali, in 1982. The dams were completed in 1986 and 1988. A few years before, in 1979, Senegal had begun - at the request of the IMF and the World Bank - the first phase of its structural adjustment program, financed by US AID and the Caisse Centrale de Coopération Economique. Among the first State corporation to be closed down was ONCAD, the groundnut marketing board; when it shut its doors it left a deficit of around eight thousand million CFA francs. In the mid-1980's, the first results of the structural program were judged to be unsatisfactory, and a more draconian Adjustment Plan was put into operation from 1985 to 1990. It was designed to remove subsidies on basic goods, raise taxes and prices, and freeze wages. In 1984, the Nouvelle Politique Agricole was formulated, ostensibly to enhance effective participation by the rural population in the development process. SAED was expected to withdraw gradually, in favor of peasant farmers. Subsidies for fertilizer and seed were also removed. Reports concerning meetings, seminars, project results, and so forth, showed that SAED nevertheless continued its policy of constructing irrigated parameters in the Bakel area. It was still very much around, even in 1990.

The members of the Federation were equally active during the 1980's. With help from various NGO's they set up literacy programs, numeracy classes, and training in account-keeping for tractor drivers. They supported women's gardens, set up a mechanic shop and, as already mentioned, installed its own fuel tank reserves, to supply farmers on a cash for fuel basis. They also built up storage facilities for fertilizers, ordered directly from a big supplier. Their aim to become independent from SAED was slowly being accomplished.

1989 was the year when Senegal's conflict with Mauritania broke out. Fula herders turned out their flocks into the cultivated fields; the Soninke expelled them. War broke out between Fula herders, backed up by soldiers, and Soninke farmers, leaving several farmers dead and over a dozen taken hostage. The property of Mauritanian Moors and Fula living in Senegal was destroyed; Mauritanians retaliated by destroying the property of "Fleuve" households living in their country. These events may have retarded progress in Federation activities, but it did not halt them.

From 1990 onwards Jaabe So - at the urging of, and with support from Christian Aid devoted himself to meeting peasant farmers all along the River, explaining the work of the Kungani Federation to them, and encouraging them to form their own federations. New foreignfunded projects in the Bakel area came and went. The Caisse Française de Développement, for example, was funding a large market gardening project. But the women gardeners of Kungani were not eligible. And no provisions were made for transporting the product to the market.

In 1993, it was determined that the Federation had received from several foreign donors $\$ 778,000$ in total funding in the years 1981-1993. To show for the money there stood buildings, fuel tanks, fertilizer stores, tractors, threshing machines, and three cars. All in good working order. By way of contrast, US AID had received \$15,520,000 from 1974-1990, and all they had to show for the money were old pumps, an empty SAED building, abandoned vehicles and equipment. The Irrigation and Water Management Project's declared aims, to build effective irrigation systems, had gone up in smoke; paper promises!

There was no end to the Bakel Federation's saga, however. In 1991/1992, for example, the Kungani harvest of 165 tons of maize and sorghum was just over half of what they required. The 


\section{Reviews}

documents emerging from the meeting that Christian Aid had helped organize in Ndioum in 1992 clearly stated that the future of all harmonious development lied in having strong and well integrated farmers' organizations. Riverside villages needed to make a success of irrigated farming, while continuing to practice flood-recession and rain-fed agriculture, by having irrigation perimeters properly rebuilt and extended. In 1994 SAED received funding from Kuwait for "aménagements," with a mandate from the Minister of Agriculture to organize federations of peasant farmers; as if the Bakel Federation had never existed! Twenty years of invaluable time, money and effort had gone into the creation of federations that would unite the River Valley peasant farmers. And, still, in 1994, as the book ends, the spectre of SAED - with its Stateoriented, centralist perspective- continues to loom large.

Adams and So's wonderful book leaves the reader with a firm conviction. If the million in foreign aid the Senegalese government had spent financing its own inflated bureaucracy, and its misguided, chimeric schemes in the River Valley, had, instead, been managed by the federations of peasant farmers themselves, a genuine agricultural revolution would have taken place. The goal of a harmonious, just and successful peasant development can still be achieved. But only if the actors themselves - peasant farmers and their families - are empowered to make the decisions that benefit them, and only them. The rest - increased agricultural production, assured food security, a genuine private sector, decreased grain imports, a healthy environment - would naturally follow. The premise upon which this book is founded - namely that peasant farmers know best what kind of development benefits them, and by implication the State - is fundamental and unassailable.

\section{Sociology, Environmentalism, Globalization, by Steven Yearley. London: SAGE Publications (1996) 161 pages.}

\section{Reviewed by Peter S. Wenz, Professor of Philosophy, University of Illinois at Springfield}

This book discusses the sociology of globalization, which concerns the extent of globalization, as well as its causes and effects, in many areas of social life, such as business, entertainment, and banking. The focus here is environmental issues. Yearley claims that the global nature of many environmental issues is overstated, that science and economics cannot provide value-neutral descriptions of problems and prescriptions for solutions, and that many global organizations and interest groups have a Northern bias. His theses are important, his writing is clear, and his reasoning is convincing.

Yearly argues persuasively in Chapter 1 that we live in an era of unprecedented globalization. Subjectively "people are increasingly viewing themselves as participants in a globalized world." Objectively, there is "the rise to prominence of more and more global processes." (p. 1). Thus, "there are good grounds for taking the idea of globalization seriously" (p. 23). Yearley discusses the idea under five headings: finance, communications, culture, business, and politics.

Sociologists tend to under-emphasize globalization because the discipline arose during the hegemony of the nation-state, whose supposedly separate societies became the focus of sociological attention. But nation-states are relatively recent phenomena and are so far from being natural that the consciousness of belonging to such a nation must continually be reinforced in 